\title{
Nutritional value changes in response to temperature, microalgae mono and mixed cultures
}

\author{
Alteraçôes no valor nutricional de microalgas em resposta a variação de temperatura, \\ cultivo unialgal e misto
}

Frederico Pacheco Militão* (D), Valéria de Oliveira Fernandes ${ }^{1}$ (D), Kathiani Victor Bastos ${ }^{1}$ (D), Aline Paternostro Martins ${ }^{2}$ (D), Pio Colepicolo ${ }^{2}$ (D) and Levi Pompermayer Machado ${ }^{3}$ (D)

${ }^{1}$ Centro de Ciências Humanas e Naturais, Universidade Federal do Espírito Santo - UFES, Av. Fernando Ferrari, 514, Goiabeiras, CEP 29075-910, Vitória, ES, Brasil

${ }^{2}$ Instituto de Química, Departamento de Bioquímica, Universidade de São Paulo - USP, Av. Prof. Lineu Prestes, 748, Vila Universitária, CEP 05508-000, São Paulo, SP, Brasil

${ }^{3}$ Departamento de Engenharia de Pesca, Universidade Estadual de São Paulo - UNESP, Av. Nelson Brihi Badur, 430, Vila Tupy, CEP 11900-000, Registro, SP, Brasil

*e-mail: fredericomilitao@gmail.com

Cite as: Militão, F.P. et al. Nutritional value changes in response to temperature, microalgae mono and mixed cultures. Acta Limnologica Brasiliensia, 2019, vol. 31, e17.

Abstract: Aim: The response of mixed cultures and monocultures of Pseudopediastrum boryanum (Turpin) E. Hegewald and Scenedesmus obliquus (Turpin) Kützing was assessed in the laboratory at three different temperatures: 20,30 and $40{ }^{\circ} \mathrm{C}$. The change in biomass and biochemical composition of these cultures was evaluated. Methods: Microalgae were placed in a batch culture over 21-days in ASM1 medium. Cell density was directly counted every two days using a Fuchs-Rosenthal hemocytometer. Chlorophyll ' $a$ ' and total carotenoids were extracted twice. Protein, carbohydrate, total lipid and fatty acid contents were determined at the end of the experiment. Results: Cultures grown in $40{ }^{\circ} \mathrm{C}$ exhibited no growth. However, there was increased cell density $\left(13.6 \times 10^{6}\right.$ cell. $\left.\mathrm{mL}^{-1}\right)$ and biomass $\left(55 \mathrm{~g} . \mathrm{L}^{-1}\right)$ in the $S$. obliquus monoculture at $30^{\circ} \mathrm{C}$. High protein concentrations $\left(672.6 \mathrm{mg} \cdot \mathrm{g}^{-1}\right)$ were observed in monocultures $P$. boryanum and S. obliquus at $20^{\circ} \mathrm{C}$ treatments. There were high

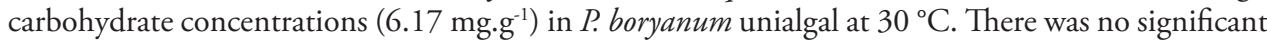
difference in total lipid content between S. obliquus (95.5 mg.g $\left.\mathrm{g}^{-1}\right)$, P. boryanum $\left(96.3 \mathrm{mg} . \mathrm{g}^{-1}\right)$ and the mixed culture at $20{ }^{\circ} \mathrm{C}\left(105.3 \mathrm{mg} \cdot \mathrm{g}^{-1}\right)$. FAMEs varied significantly regarding the number of unsaturated components, which predominantly consisted of fatty acids with two or more unsaturated bonds. Conclusions: The biomass of the treatments analyzed was rich in proteins and essential fatty acids (such as linolenic acid), yet low in carbohydrate content, suggesting its potential use as a food supplement. Our results indicate that mixed culture of $P$. boryanum and $S$. obliquus was inefficient in cultivating biomass or biochemical compounds as compared to the unialgal cultivations. However, algae grown together showed better stability in their biochemical composition in response to changes in temperature, an important factor for microalgae production in open ponds and in food safety measures. These results suggest the consortia among different species of microalgae should be tested to determine better methodologies for the production of biomass and metabolites with greater stability towards environmental factors.

Keywords: mixed cultivation; Pseudopediastrum; Scenedesmus; biomass; food security. 
Resumo: Objetivo: Avaliar o desenvolvimento de Pseudopediastrum boryanum (Turpin) E. Hegewald e Scenedesmus obliquus (Turpin) Kützing em cultivos unialgais e mistos, em três diferentes temperaturas, 20,30 e $40^{\circ} \mathrm{C}$, em escala laboratorial, em termos de biomassa e composição bioquímica. Métodos: $\mathrm{O}$ cultivo foi do tipo batelada, em meio ASM1. A densidade celular foi determinada por contagem direta em hemocitômetro a cada dois dias. As análises dos principais pigmentos se deram em dois tempos e as análises de proteínas, carboidratos, lipídeos totais e perfil de ésteres metílicos apenas ao final do experimento. Resultados: Não foi registrado crescimento celular nas cepas cultivadas em $40{ }^{\circ} \mathrm{C}$. Incremento na densidade celular $\left(13.6 \times 10^{6}\right.$ cell. $\left.\mathrm{mL}^{-1}\right)$ e biomassa $\left(55\right.$ g. $\left.\mathrm{L}^{-1}\right)$ foram registrados na cultura unialgal de S. obliquus em $30^{\circ} \mathrm{C}$. Elevadas concentraçôes de proteínas (672.6 mg.g ${ }^{-1}$ ) foram observadas nos cultivos unialgais de P. boryanum e de $S$. obliquus em $20^{\circ} \mathrm{C}$ e de carboidratos $\left(6.17 \mathrm{mg} . \mathrm{g}^{-1}\right)$ apenas no cultivo unialgal de $P$. boryanum em $30^{\circ} \mathrm{C}$. Os FAMEs (fatty acid methyl esteres) variaram significativamente em relação ao número de insaturaçôes, sendo constituídos em sua maioria por ácidos graxos com duas ou mais insaturações. Conclusóes: A biomassa dos tratamentos analisados foi rica em proteínas, ácidos graxos essenciais, como o ácido linolênico, e apresentou baixo teor de carboidratos, sugerindo seu potencial uso como suplemento alimentar. Nossos resultados indicam que a cultura mista de P. boryanum e $S$. obliquus não foi uma condição eficiente para a produção de biomassa ou compostos bioquímicos. No entanto, algas cultivadas em consórcio apresentaram melhor estabilidade em sua composição bioquímica em resposta a mudanças de temperatura, fator importante para a produçáo de microalgas em lagoas abertas e para garantir a segurança alimentar. Estes resultados sugerem que os consórcios entre diferentes espécies de microalgas devem ser testados para determinar melhores metodologias para produção de biomassa e metabólitos com maior estabilidade à fatores ambientais.

Palavras-chave: cultivo misto; Pseudopediastrum; Scenedesmus; biomassa; segurança alimentar.

\section{Introduction}

Microalgae present high rates of growth and biomass production (Becker, 2013; Dismukes et al., 2008), extensive chemical and metabolic diversity, and great ecological plasticity. All of these traits allow microalgae to respond quickly to varying environmental conditions (Hannon et al., 2010; Lourenço, 2006). These attributes also suggest that microalgae show promise in producing molecules that can be used in biofuel production, as well as molecules with properties that are beneficial for humans and animals (Ohse et al., 2007).

There is currently considerable effort in researching species with improved lipid production for technologies that require biodiesel; however, the yield is still not economically viable (Clarens et al., 2010; Milledge, 2011; Soratana et al., 2014). Current yields are estimated at between $\$ 9$ and $\$ 25$ USD per gallon of oil extracted from cultivation in open ponds and between $\$ 15$ and $\$ 40$ per gallon of the same oil extracted from microalgae grown in closed photobioreactors (Kirrolia et al., 2013).

Therefore, investigating endogenous or bioengineered co-products together with microalgae oil would beneficially impact the economics of algae-based biofuels. Nutrients and secondary metabolites constitute a considerable fraction of the residual biomass and present a wide variety of nutraceutical and pharmaceutical applications, as well as agricultural inputs (Dismukes et al., 2008; Hannon et al., 2010; Khan et al., 2009; Kirrolia et al., 2013).
Manipulating the algal growth environment can alter the growth characteristics and chemical composition of cultured cells. Consequently, there is considerable research that focuses on altering the physical, chemical and biological conditions of various microalgae crops to induce the production of target compounds and generate biomass, thereby improving the feasibility of the production of algae biofuels (Lourenço, 2006; Miao et al., 2004).

Currently, commercial-scale microalgae cultivation is mainly carried out with monocultures in open pond systems (Chisti, 2007), due to its low cost of implantation, maintenance and expansion (Coplin, 2012; Milledge, 2011). However, monocultures in open pond systems are subject to temperature variations, which directly affects the growth and metabolic activities of these microalgae (Lourenço, 2006; Li et al., 2011), and allows the entry of other species of microalgae and zooplankton, compromising the uniformity of the population and the quality of the final product. Therefore, using a greater number of species in the same cultivation unit may be advantageous in open pond systems, given that mixed crops have a higher stability and can better utilize available resources, producing more biomass and lipids (Coplin, 2012; Hannon et al., 2010; Smith et al., 2010).

This study evaluated the performance of mixed and monocultures of Pseudopediastrum boryanum (Turpin) E. Hegewald and Scenedesmus obliquus (Turpin) Kützing under three different temperatures $\left(20,30\right.$ and $\left.40{ }^{\circ} \mathrm{C}\right)$. Both biomass and metabolite production (fatty acid profile and total lipid 
content, carbohydrates, proteins and pigments) were analyzed to determine the effect of differing culture conditions on the biomass and aggregate products of microalgae.

\section{Material and Methods}

\subsection{Experimental design}

The species of microalgae, $P$. boryanum and S. obliquus, were obtained from the culture collection of microalgae at the Laboratory of Taxonomy and Ecology of Continental Algae (LATEAC), Federal University of Espírito Santo. Both species were collected and isolated from the Juara Lagoon (Serra, Espírito Santo, Brazil). These species were selected through previous tests that showed biochemical potential of their biomass, when cultivated separately.

Microalgae were cultivated in batch incubators (Electrolab, EL 202/3; Brazil) to investigate the effect of three different temperatures $\left(20,30\right.$ and $\left.40{ }^{\circ} \mathrm{C}\right)$. For the incubations, algae were grown in $3 \mathrm{~L}$ Erlenmeyer flasks, containing 2.5 L of ASM1 medium (Gorham et al., 1964), with an initial $\mathrm{pH}$ of $7 \pm 0.05$. A constant aeration of 3.5 L. $\mathrm{min}^{-1}$ of air, without direct sprinkling of $\mathrm{CO}_{2}$, was maintained under a $12 / 12 \mathrm{~h}$ light/dark photoperiod with maximum illuminance of $40 \mu \mathrm{mol} . \mathrm{m}^{-2} \cdot \mathrm{s}^{-1}$. Three treatments were carried in triplicate at each temperature. The treatments are P20/P30/P40, S20/S30/S40 and M20/M30/M40 corresponding to the monocultures of P. boryanum, S. obliquus and the mixed culture at the different temperatures, respectively. The initial inoculum was $1.5 \times 10^{5}$ cells. $\mathrm{mL}^{-1}$ for the unialgal cultures and $7.5 \times 10^{4}$ cells. $\mathrm{mL}^{-1}$ of each species for the mixed cultures, totaling $1.5 \times 10^{5}$ cells. $\mathrm{mL}^{-1}$. A predetermined sequence of rotation of the Erlenmeyer flasks in the incubators was established, to ensure uniformity of the culture conditions. The experiment lasted 21 days.

\subsection{Growth assessment}

Cell density was determined by direct counting in a Fuchs-Rosenthal hemocytometer under an optical microscope (Olympus, CX41RF; Philippines), every 2 days of the experiment.

Dry biomass was determined every 4 days by filtering $15 \mathrm{~mL}$ aliquots through glass fiber filters (Macherey-Nagel, GF1 47 mm; Germany), followed by oven drying at $65^{\circ} \mathrm{C}$ until constant weight (Lourenço, 2006).

Growth rate $(K)$ and mean doubling time $(G)$ were calculated using the values obtained from the exponential growth phase, by the following equation:
$K=(\ln (N 2)-\ln (N 1)) /(T 2-T 1)$, where $N 1$ and $N 2$ are the numbers of cells at times $T 1$ and $T 2$, respectively. Taking the values of $K$, the mean doubling time was calculated as $G=\ln (2) / K$. The maximum yield $\left(Y_{\max }\right)$ was calculated, by subtracting the highest density value obtained (cells. $\mathrm{mL}^{-1}$ ) by the initial inoculated value (Fogg $\&$ Thake, 1987).

\subsection{Carbohydrates, proteins, total lipids and pigments}

Total carbohydrate concentrations were determined following the procedure initially described by Dubois et al. (1956) and modified by Cuzzuol \& Clippel (2009). The Quick Start TM Bradford Protein Assay kit (Biorad; United States) was used to quantify the total soluble protein, based on the Bradford (1976) method. Total lipids were extracted and analyzed according to Bligh \& Dyer (1959). Chlorophyll ' $a$ ' and total carotenoids were extracted in $90 \%$ acetone and their concentrations were measured spectrophotometrically (Thermo Scientific, Aquamate plus; United States), following the established protocols of Lorenzen (1967) and Strickland \& Parsons (1968), respectively. The concentrations of chlorophyll ' $a$ ' and carotenoids were evaluated on the 10th and 21st days of the experiment; protein, carbohydrate and total lipid analyses were evaluated only at the end of the experiment.

\subsection{Analysis of fatty acids}

The macerated lyophilized algae were suspended in a phosphate-buffered saline solution, followed by the addition of $42 \mu \mathrm{L} \mathrm{C13:0} \mathrm{analytical} \mathrm{standard}$ (glyceryl tritridecanoate) solution $\left(5 \mathrm{mg} \cdot \mathrm{mL}^{-1}\right.$ in hexane) and $4.15 \mathrm{~mL}$ chloroform/methanol/water $(2: 2: 1 \mathrm{v} / \mathrm{v} / \mathrm{v})$. The mixture was centrifuged, and the chloroform phase was transferred to another flask and dried under $\mathrm{N}_{2}$ gas. The total lipid content was determined gravimetrically, and the dry lipid extract was methylated to assess fatty acid content.

The methylation reaction of fatty acids to fatty acid methyl esters (FAMEs) was performed by dissolving the dry lipid extract in $500 \mu \mathrm{L} \mathrm{BF}_{3}$ ( $7 \%$ in methanol). The mixture was then incubated for one hour at $100^{\circ} \mathrm{C}$. Next, $1.25 \mathrm{~mL}$ of water were added at room temperature, and the FAMEs were extracted with $500 \mu \mathrm{L}$ hexane.

The FAMEs were analyzed by gas chromatography coupled with mass spectrometry (Shimadzu, QP2010; Japan), using a 30-m fused silica capillary column (VF-Wax with $0.25 \mu \mathrm{m}$ film; Agilent). A sample $(1 \mu \mathrm{L})$ was injected at $220{ }^{\circ} \mathrm{C}$ in split mode. Helium was used as the carrier gas, at a flow 
rate of $1 \mathrm{~mL} \cdot \mathrm{min}^{-1}$. The procedure had the following temperature ramp: initial temperature of $60^{\circ} \mathrm{C}$ with an increase of $5^{\circ} \mathrm{C} \cdot \mathrm{min}^{-1}$ up to $260^{\circ} \mathrm{C}$, which was maintained for 10 minutes.

The standard used to identify the peaks was Supelco 37 (47885-U). The fatty acids were identified through comparing retention times with standards and/or by comparing their mass spectra with the existing NIST spectral library. The FAMEs that were not included in the standard and that presented a similarity index below $90 \%$ were not considered.

Most FAMEs were quantifiable with the regression of the standard curve for the respective FAMEs of the Supelco 37 standard. For those FAMEs not in the Supelco standard, quantification was performed through considering the concentration of the internal standard (C13:0), because the peak area was proportional to the FAME concentration. Analysis of fatty acids were evaluated only at the end of the experiment. Based on the fatty acid profile, the ratio between omega- 3 and omega- 6 fatty acids $(\omega-3 / \omega-6)$ was calculated.

\subsection{Statistical analysis}

The data obtained from the growth, dry mass, total water-soluble protein, lipid, carbohydrate, pigment and fatty acid analyses were subjected to the Shapiro-Wilk normality analysis. The parametric data were then evaluated by ( 2 temperature $\times 3$ culturing modes $)$ factorial analysis of variance (ANOVA), for the pigment and dry mass data, the time factor was included, and Tukey's test at 5\% probability level. All statistical analyses were performed using ASSISTAT (version 7.7 beta; Federal University of Campina Grande, PB, Brazil) (Silva \& Azevedo, 2016).

\section{Results}

\subsection{Growth and dry mass}

There was no apparent growth for those cultures grown at $40{ }^{\circ} \mathrm{C}$. Temperature did affect the growth parameters $K(\mathrm{~F}=21.2867, \mathrm{p}<0.001)$ and $G(\mathrm{~F}=7.9202, \mathrm{p}=0.0064)$. However, although the $Y_{\max }$ value was significantly different between treatments $(\mathrm{F}=64.4840, \mathrm{p}<0.001)$, it was not affected by temperature $(\mathrm{F}=1.5237, \mathrm{p}=0.2572)$ (Table 1).

Temperature did not affect biomass $(\mathrm{F}=2.4984$, $\mathrm{p}=0.052)$. Therefore, the cultivation time was primarily responsible for this improved biomass yield $(\mathrm{F}=15.2790, \mathrm{p}<0.001)$ (Table 2$)$. There was a significant increase in biomass, compared to days 5 and 21 , in all treatments $(F=8.9783$,

Table 1. Parameters of growth of unialgal and mixed cultures.

\begin{tabular}{cccrc}
\hline aSample & $\begin{array}{c}\boldsymbol{K} \\
\left(\mathbf{d}^{-1}\right)\end{array}$ & $\begin{array}{c}\mathbf{G} \\
\text { (day) }\end{array}$ & $\begin{array}{c}\boldsymbol{Y}_{\text {max }} \\
\left.\text { (cells.mL } \mathbf{H}^{-1}\right)\end{array}$ & Log phase (days) \\
\hline P20 & $0.39 \pm 0.11 \mathrm{bA}$ & $1.79 \pm 0.05 \mathrm{aB}$ & $2.24 \times 10^{6} \mathrm{aC}$ & $3-5$ \\
S20 & $0.21 \pm 0.00 \mathrm{aB}$ & $3.25 \pm 0.05 \mathrm{bA}$ & $10.94 \times 10^{6} \mathrm{aA}$ & $1-19$ \\
M20 & $0.21 \pm 0.01 \mathrm{aB}$ & $3.49 \pm 0.37 \mathrm{bA}$ & $6.42 \times 10^{6} \mathrm{bB}$ & $1-19$ \\
P30 & $0.72 \pm 0.02 \mathrm{aA}$ & $0.99 \pm 1.40 \mathrm{aB}$ & $2.26 \times 10^{6} \mathrm{aC}$ & $3-9$ \\
S30 & $0.13 \pm 0.03 \mathrm{bB}$ & $5.29 \pm 0.78 \mathrm{aA}$ & $13.67 \times 10^{6} \mathrm{aA}$ & $1-21$ \\
M30 & $0.13 \pm 0.00 \mathrm{bB}$ & $5.73 \pm 0.23 \mathrm{aA}$ & $9.16 \times 10^{6} \mathrm{aB}$ & $1-21$ \\
\hline
\end{tabular}

${ }^{\text {aP2}} 20, \mathrm{~S} 20$ and M20 correspond to P. boryanum, S. obliquus and the mixed culture at $20{ }^{\circ} \mathrm{C} ; \mathrm{P} 30, \mathrm{~S} 30$ and M30 correspond to P. boryanum, S. obliquus and the mixed culture at $30^{\circ} \mathrm{C}$. Values followed by different letters differ statistically from each other $(\mathrm{p}<0.01)$. Lowercase letters compare the respective treatment at both temperatures. Uppercase letters compare treatments within the same temperature. $K=$ growth rate; $G=$ doubling time; $Y_{\max }=$ maximum yield. Mean $\pm \mathrm{SD}(\mathrm{n}=3$ cultivations).

Table 2. Biomass variation (dry weight) during cultivation in g.: $L^{-1}$.

\begin{tabular}{cccccc}
\hline aSample & Day 5 $\mathbf{( g . \mathbf { L } ^ { - 1 } )}$ & Day 10 $\mathbf{( g . \mathbf { L } ^ { - 1 } )}$ & Day 13 $\mathbf{( g . \mathbf { L } ^ { - 1 } )}$ & Day 17 $\mathbf{( g . \mathbf { L } ^ { - 1 } )}$ & Day 21 $\left(\mathbf{g} \cdot \mathbf{L}^{-1}\right)$ \\
\hline P20 & $0.09 \pm 0.01 \mathrm{bAe}$ & $0.16 \pm 0.03 \mathrm{bAd}$ & $0.22 \pm 0.01 \mathrm{aBc}$ & $0.36 \pm 0.02 \mathrm{aA} b$ & $0.48 \pm 0.04 \mathrm{aBa}$ \\
S20 & $0.03 \pm 0.01 \mathrm{aBd}$ & $0.15 \pm 0.02 \mathrm{aAc}$ & $0.20 \pm 0.06 \mathrm{aBc}$ & $0.33 \pm 0.02 \mathrm{aA} b$ & $0.56 \pm 0.06 \mathrm{aA} a$ \\
M20 & $0.12 \pm 0.02 \mathrm{aAc}$ & $0.15 \pm 0.00 \mathrm{aAc}$ & $0.28 \pm 0.06 \mathrm{aA} b$ & $0.27 \pm 0.05 \mathrm{aB} b$ & $0.42 \pm 0.07 \mathrm{aCa}$ \\
P30 & $0.16 \pm 0.03 \mathrm{aAd}$ & $0.21 \pm 0.01 \mathrm{aAc}$ & $0.25 \pm 0.03 \mathrm{aAc}$ & $0.30 \pm 0.04 \mathrm{bA} b$ & $0.40 \pm 0.05 \mathrm{bBa}$ \\
S30 & $0.04 \pm 0.00 \mathrm{aBd}$ & $0.15 \pm 0.01 \mathrm{aBc}$ & $0.18 \pm 0.01 \mathrm{aBc}$ & $0.27 \pm 0.00 \mathrm{bA} b$ & $0.55 \pm 0.00 \mathrm{aAa}$ \\
M30 & $0.08 \pm 0.01 \mathrm{bBd}$ & $0.15 \pm 0.01 \mathrm{aBc}$ & $0.27 \pm 0.03 \mathrm{aA} b$ & $0.32 \pm 0.06 \mathrm{aA} b$ & $0.37 \pm 0.01 \mathrm{aBa}$
\end{tabular}

${ }^{a}$ P20, S20 and M20 correspond to P. boryanum, S. obliquus and mixed culture at $20{ }^{\circ} \mathrm{C} ; \mathrm{P} 30, \mathrm{~S} 30$ and M30 correspond to P. boryanum, S. obliquus and mixed culture at $30^{\circ} \mathrm{C}$. Values followed by different letters differ statistically from each other $(\mathrm{p}<0.01)$. Lowercase letters compare the respective treatment at both temperatures. Uppercase letters compare the treatments within the same temperature. Lowercase italics compare the treatments at the same temperature at different times. Mean $\pm S D(n=3$ cultivations $)$. 
$\mathrm{p}<0.001$ ), with S30 and S20 crops presenting the highest biomass at the end of the experiment.

\subsection{Total carbohydrates, water-soluble proteins and lipids}

The total carbohydrate, water-soluble protein and lipid contents of the different treatments are listed in Table 3. Although temperature had a significant influence on the carbohydrate concentrations $(\mathrm{F}=13.0323, \mathrm{p}=0.0009)$, they were mainly correlated with being in a mono- or mixed culture $(\mathrm{F}=36.5491, \mathrm{p}<0.001)$.

The highest carbohydrate concentration, $6.17 \mathrm{mg} \cdot \mathrm{g}^{-1}$ dry weight (DW), was recorded in the monoculture of $P$. boryanum at $30{ }^{\circ} \mathrm{C}(\mathrm{P} 30)$. It was higher $(\mathrm{F}=30.8861, \mathrm{p}=0.0006)$ than the corresponding values found for the mixed culture (M30) and the unialgal S. obliquus culture (S30) at the same temperature, respectively.

A comparative test of means showed that as the temperature lowered from 30 to $20{ }^{\circ} \mathrm{C}$, there was significant decrease in carbohydrate content of the monoculture of $P$. boryanum ( $\mathrm{F}=14,1867$, $\mathrm{p}=0.0196)$. In contrast, there was an increase in carbohydrate content in the monoculture of S. obliquus $(\mathrm{F}=11.0115, \mathrm{p}=0.0294)$. The carbohydrate content of the mixed culture did not change with respect to temperature $(\mathrm{F}=0.0908, \mathrm{p}=7781)$.

The temperature and the type of culture did not have a significant influence on the total soluble protein concentration $(\mathrm{F}=3.4336, \mathrm{p}=0.0662)$. There was an increase in the protein content only in monocultures of $P$. boryanum, when temperature decreased to $20{ }^{\circ} \mathrm{C}(\mathrm{F}=13.4697, \mathrm{p}=0.214)$. However, total lipid content is significantly affected to the temperature $(\mathrm{F}=94.430, \mathrm{p}<0.001)$. In all treatments, the decrease in temperature to $20^{\circ} \mathrm{C}$ corresponded to an increase in the concentration of total lipids.

\subsection{Chlorophyll 'a' and total carotenoids}

The concentrations of chlorophyll ' $a$ ' and total carotenoids (Table 4) were significantly affected by culture time $(\mathrm{F}=123.0587, \mathrm{p}<0.001)$.

Table 3. Content of total carbohydrates, water-soluble proteins and total lipids of Pseudopediastrum boryanum, Scenedesmus obliquus grown in mono- and mixed culture at 20 and $30^{\circ} \mathrm{C}$.

\begin{tabular}{|c|c|c|c|c|c|c|}
\hline aSample & $\begin{array}{l}\text { Carbohydrate } \\
\left(\mathrm{mg}^{-1} \mathrm{~g}^{-1}\right)\end{array}$ & $\%$ (DW) & $\begin{array}{l}\text { Protein } \\
\left(\mathrm{mg}^{\left.-g^{-1}\right)}\right.\end{array}$ & $\%$ (DW) & $\begin{array}{l}\text { Total lipid } \\
\left(\mathrm{mg}^{\left.-g^{-1}\right)}\right.\end{array}$ & $\%$ (DW) \\
\hline P20 & $4.36 \pm 0.23 \mathrm{bA}$ & 0.44 & $672.60 \pm 5.7 \mathrm{aA}$ & 67.30 & $96.30 \pm 3.1 \mathrm{aA}$ & 9.60 \\
\hline $\mathrm{S} 20$ & $3.33 \pm 0.50 \mathrm{aA}$ & 0.33 & $672.60 \pm 62.6 \mathrm{aA}$ & 67.30 & $95.50 \pm 2.5 \mathrm{aA}$ & 9.50 \\
\hline M20 & $3.98 \pm 0.30 \mathrm{aA}$ & 0.40 & $359.50 \pm 17.1 \mathrm{aB}$ & 35.90 & $105.30 \pm 4.7 \mathrm{aA}$ & 10.50 \\
\hline P30 & $6.17 \pm 0.80 \mathrm{aA}$ & 0.62 & $466.60 \pm 97.1 \mathrm{bA}$ & 46.70 & $78.50 \pm 2.5 \mathrm{bAB}$ & 7.80 \\
\hline $\mathrm{S} 30$ & $2.17 \pm 0.34 \mathrm{bC}$ & 0.22 & $581.80 \pm 10.0 \mathrm{aA}$ & 58.20 & $82.50 \pm 7.5 \mathrm{bA}$ & 8.30 \\
\hline M30 & $3.86 \pm 0.64 \mathrm{aB}$ & 0.39 & $326.50 \pm 85.3 \mathrm{aB}$ & 32.60 & $68.70 \pm 6.6 \mathrm{bB}$ & 6.90 \\
\hline
\end{tabular}

aP20, S20 and M20 correspond to P. boryanum, S. obliquus and mixed culture at $20^{\circ} \mathrm{C} ; \mathrm{P} 30, \mathrm{~S} 30$ and M30 correspond to $P$. boryanum, $S$. obliquus and mixed culture at $30^{\circ} \mathrm{C}$. Values followed by different letters differ statistically from each other $(\mathrm{p}<0.01)$. Lowercase letters compare the respective treatment at both temperatures. Uppercase letters compare treatments within the same temperature. $\mathrm{DW}=$ dry weight. Mean $\pm \mathrm{SD}(\mathrm{n}=3$ cultivations).

Table 4. Chlorophyll ' $a$ ' and total carotenoid contents of Pseudopediastrum boryanum and Scenedesmus obliquus, grown individually and in mixed culture, at 20 and $30^{\circ} \mathrm{C}$, in two periods of cultivation.

\begin{tabular}{|c|c|c|c|c|}
\hline \multirow[b]{2}{*}{ aSample } & \multicolumn{2}{|c|}{ First period (Day 10) } & \multicolumn{2}{|c|}{ Second period (Day 21) } \\
\hline & 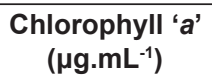 & $\begin{array}{c}\text { Carotenoids } \\
\left(\mu \mathrm{g} \cdot \mathrm{mL}^{-1}\right)\end{array}$ & 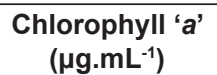 & $\begin{array}{c}\text { Carotenoids } \\
\left(\mu \mathrm{g} \cdot \mathrm{mL}^{-1}\right)\end{array}$ \\
\hline P20 & $1.8 \pm 0.32 \mathrm{aAa}$ & $0.5 \pm 0.04 \mathrm{aA} b$ & $2.3 \pm 0.06 \mathrm{aBa}$ & $0.8 \pm 0.05 \mathrm{bAa}$ \\
\hline $\mathrm{S} 20$ & $1.3 \pm 0.28 \mathrm{aAa}$ & $0.5 \pm 0.04 \mathrm{aA} b$ & $1.7 \pm 0.23 \mathrm{aBa}$ & $0.7 \pm 0.12 \mathrm{aAa}$ \\
\hline M20 & $1.8 \pm 0.31 \mathrm{aA} b$ & $0.6 \pm 0.09 \mathrm{aA} b$ & $3.2 \pm 0.60 \mathrm{aAa}$ & $1.0 \pm 0.20 \mathrm{aAa}$ \\
\hline P30 & $1.2 \pm 0.22 \mathrm{bB} b$ & $0.4 \pm 0.12 \mathrm{aAB} b$ & $3.0 \pm 0.30 \mathrm{aAa}$ & $1.0 \pm 0.04 \mathrm{aAa}$ \\
\hline $\mathrm{S} 30$ & $1.1 \pm 0.13 \mathrm{aB} b$ & $0.3 \pm 0.06 \mathrm{aB} b$ & $2.3 \pm 0.08 \mathrm{aBa}$ & $1.0 \pm 0.04 \mathrm{aAa}$ \\
\hline M30 & $1.8 \pm 0.27 \mathrm{aA} b$ & $0.6 \pm 0.03 a \mathrm{~A} b$ & $3.1 \pm 0.61 \mathrm{aAa}$ & $0.9 \pm 0.25 \mathrm{aAa}$ \\
\hline
\end{tabular}

${ }^{a}$ P20, S20 and M20 correspond to P. boryanum, S. obliquus and mixed culture at $20{ }^{\circ} \mathrm{C} ; \mathrm{P} 30, \mathrm{~S} 30$ and M30 correspond to P. boryanum, S. obliquus and mixed culture at $30^{\circ} \mathrm{C}$. Values followed by different letters differ statistically from each other $(\mathrm{p}<0.01)$. Lowercase letters compare the respective treatment at both temperatures. Uppercase letters compare the treatments within the same temperature. Lowercase italics compare the treatments at the same temperature at different times. Mean $\pm S D$ ( $n=3$ cultivations). 


\subsection{Profile of Fatty Acid Methyl Esters (FAMEs)}

Concentrations of the FAMEs and their unsaturation contents for mono and mixed cultures of $P$. boryanum and S. obliquus at different temperatures, as well as the $\omega-3 / \omega-6$ ratio, are listed in Table 5. The composition of the FAMEs varied significantly with regard to the number of unsaturated components. One exception is for the M20 treatment, in which there was a higher content of monounsaturated fatty acids (MUFAs); all other treatments, however, were constituted predominantly by fatty acids with two or more unsaturated components.

There was an inverse relationship between the $\omega-3 / \omega-6$ ratio and the total concentration of the FAMEs in the temperature treatments $(\mathrm{F}=21.3996$, $\mathrm{p}=0.0005)$. The only exception was the unialgal cultivation of $P$. boryanum, where was directly proportional to the $\omega-3 / \omega-6$ ratio.

The composition of the FAMEs extracted from the microalgal biomass of each treatment is shown

Table 5. Concentration (mg. $\mathrm{g}^{-1}$ dry weight) of total fatty acids, saturated fatty acids (SFAs), monounsaturated fatty acids (MUFAs), polyunsaturated fatty acids (PUFAs) and $\omega-3 / \omega-6$ ratio of treatments.

\begin{tabular}{cccccc}
\hline${ }^{a}$ Sample & ${ }^{\mathrm{b}}$ SFAs & ${ }^{\mathrm{b}}$ MUFAs & ${ }^{\mathrm{b} P U F A s}$ & ${ }^{\mathrm{c}} \boldsymbol{\omega}-\mathbf{3} / \boldsymbol{\omega}-\mathbf{6}$ ratio & ${ }^{\mathrm{c}}$ Total \\
\hline P20 & $21.1 \pm 0.80 \mathrm{c}$ & $33.7 \pm 0.61 \mathrm{~b}$ & $45.2 \pm 1.11 \mathrm{a}$ & $0.2: 1.0 \pm 0.0 \mathrm{aB}$ & $79.2 \mathrm{aAB}$ \\
S20 & $16.0 \pm 1.32 \mathrm{c}$ & $27.9 \pm 3.23 \mathrm{~b}$ & $56.2 \pm 2.68 \mathrm{a}$ & $3.4: 1.0 \pm 0.1 \mathrm{aA}$ & $82.7 \mathrm{aA}$ \\
M20 & $21.7 \pm 0.33 \mathrm{c}$ & $41.8 \pm 1.23 \mathrm{a}$ & $36.5 \pm 0.97 \mathrm{~b}$ & $3.4: 1.0 \pm 1.0 \mathrm{aA}$ & $73.5 \mathrm{aB}$ \\
P30 & $26.2 \pm 1.34 \mathrm{c}$ & $30.3 \pm 1.50 \mathrm{~b}$ & $43.5 \pm 2.83 \mathrm{a}$ & $0.4: 1.0 \pm 0.5 \mathrm{aB}$ & $49.2 \mathrm{bB}$ \\
S30 & $17.2 \pm 1.49 \mathrm{~b}$ & $14.0 \pm 1.65 \mathrm{~b}$ & $68.8 \pm 2.97 \mathrm{a}$ & $1.9: 1.0 \pm 0.2 \mathrm{bA}$ & $68.4 \mathrm{bA}$ \\
M30 & $28.0 \pm 1.88 \mathrm{~b}$ & $22.2 \pm 0.53 \mathrm{c}$ & $49.8 \pm 1.59 \mathrm{a}$ & $1.5: 1.0 \pm 0.4 \mathrm{bA}$ & $46.0 \mathrm{bB}$ \\
\hline
\end{tabular}

${ }^{a}$ P20, S20 and M20 correspond to P. boryanum, S. obliquus and mixed culture at $20^{\circ} \mathrm{C} ; \mathrm{P} 30, \mathrm{~S} 30$ and M30 correspond to $P$. boryanum, S. obliquus and mixed culture at $30^{\circ} \mathrm{C}$. Values followed by different letters differ statistically from

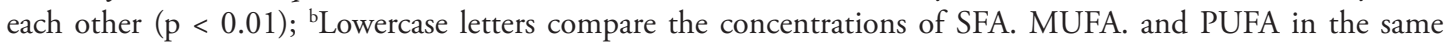
treatment; 'Lowercase letters compare the respective treatment at both temperatures. Uppercase letters compare the treatments within the same temperature. Averages followed by the same letter do not differ statistically from each other $(\mathrm{P}<0.01)$. Mean $\pm \mathrm{SD}$ ( $\mathrm{n}=3$ cultivations).

Table 6. Composition of methyl esters of fatty acids (\% of total FAME) extracted from the biomass of Pseudopediastrum boryanum and Scenedesmus obliquus in their unialgal and mixed cultures at 20 and $30^{\circ} \mathrm{C}$.

\begin{tabular}{|c|c|c|c|c|c|c|}
\hline \multirow{2}{*}{ Fatty acid } & \multicolumn{3}{|c|}{$20{ }^{\circ} \mathrm{C}(\%)$} & \multicolumn{3}{|c|}{$30{ }^{\circ} \mathrm{C}(\%)$} \\
\hline & ${ }^{\text {aP220 }}$ & ${ }^{a} \mathbf{S 2 0}$ & aM20 & aP30 & ${ }^{\mathrm{a} S 30}$ & aM30 \\
\hline Tetradecanoic (C14) & $1.0 \pm 0.05 h$ & $1.1 \pm 0.01 \mathrm{e}$ & $1.0 \pm 0.03 \mathrm{~g}$ & $1.4 \pm 0.03 f$ & $1.0 \pm 0.02 \mathrm{~h}$ & $1.8 \pm 0.04 h$ \\
\hline Pentadecanoic (C15) & $0.3 \pm 0.01 i$ & $0.4 \pm 0.01 \mathrm{e}$ & $0.4 \pm 0.02 \mathrm{~g}$ & $0.6 \pm 0.01 f$ & $0.5 \pm 0.03 \mathrm{~h}$ & $0.7 \pm 0.01 \mathrm{i}$ \\
\hline Palmitic (C16) & $15.0 \pm 0.48 c$ & $12.2 \pm 0.39 c$ & $15.2 \pm 0.27 c$ & $20.9 \pm 0.16 b$ & $14.4 \pm 0.97 c$ & $22.6 \pm$ \\
\hline Palmitoleic $(\mathrm{C} 16: 1 \Delta 9)$ & $0.2 \pm 0.01 i$ & $0.6 \pm 0.03 e$ & $0.4 \pm 0.02 g$ & $0.6 \pm 0.02 f$ & $0.7 \pm 0.02 \mathrm{~h}$ & $0.04 i$ \\
\hline Hexadecadienoic (C16:2 $\Delta 7.10)$ & $0.6 \pm 0.02 \mathrm{~h}$ & $0.5 \pm 0.02 \mathrm{e}$ & $0.4 \pm 0.01 \mathrm{~g}$ & $2.7 \pm 0.02 \mathrm{e}$ & $1.5 \pm 0.06 \mathrm{~g}$ & $1.9 \pm 0.28 h$ \\
\hline $\begin{array}{l}\text { Hexadecatrienoic } \\
(\text { C16:3 } 4 \text { 4. 7. 10) }\end{array}$ & $0.6 \pm 0.01 \mathrm{~h}$ & $0.3 \pm 0.03 e$ & $0.3 \pm 0.01 \mathrm{~g}$ & $0.9 \pm 0.03 f$ & $0.4 \pm 0.01 \mathrm{~h}$ & $0.4 \pm 0.03 i$ \\
\hline $\begin{array}{l}\text { Hexadecatrien } \\
(\mathrm{C} 16: 3 \Delta 7.10\end{array}$ & $0.7 \pm 0.09 \mathrm{~h}$ & $0.8 \pm 0.03 e$ & $0.5 \pm 0.02 \mathrm{~g}$ & $1.2 \pm 0.01 f$ & $0.7 \pm 0.01 \mathrm{~h}$ & $1.2 \pm 0.04 \mathrm{i}$ \\
\hline $\begin{array}{l}\text { Hexadecatetraenoic } \\
\text { (C16:4 } 4 \text { 4. 7. 10.13) }\end{array}$ & $4.5 \pm 0.08 \mathrm{e}$ & $10.6 \pm 0.38 c$ & $4.7 \pm 0.07 e$ & $2.6 \pm 0.16 \mathrm{e}$ & $9.8 \pm 0.13 d$ & $7.4 \pm 0.17 \mathrm{e}$ \\
\hline Heptadecanoic (C & & & & & & $0.02 i$ \\
\hline Hepta & $0.3 \pm$ & $0.3 \pm 0.02 e$ & $0.3 \pm 0.04 g$ & $0.5 \pm$ & $.03 \mathrm{~h}$ & $.03 i$ \\
\hline Steari & $1.6 \pm 0.12 g$ & $1.9 \pm 0.32 d$ & $4.1 \pm 0.06 \mathrm{e}$ & $2.4 \pm 0.01 e$ & $1.2 \pm 0.01 \mathrm{~h}$ & $2.0 \pm 0.03 h$ \\
\hline Oleic $(C 18: 1 \Delta 9)$ & $30.3 \pm 0.54 a$ & $21.8 \pm 2.78 b$ & $35.9 \pm 1.47 a$ & $22.7 \pm 0.12 a$ & $8.2 \pm 0.94 \mathrm{e}$ & $13.6 \pm 0.22 d$ \\
\hline Elaidic $(\mathrm{C} 18: 1 \Delta 9)$ & $2.1 \pm 0.09 \mathrm{~g}$ & $2.8 \pm 0.08 d$ & $2.1 \pm 0.19 f$ & $2.1 \pm 0.06 e$ & $1.7 \pm 0.45 \mathrm{~g}$ & $3.0 \pm 0.11 \mathrm{~g}$ \\
\hline Linoleic (C18:2 & & $11.4 \pm 0.89 c$ & $9.4 \pm 0.09 d$ & $18.8 \pm 0.47 c$ & $22.0 \pm 1.10 \mathrm{~b}$ & $15.7 \pm 0.53 c$ \\
\hline G-Linolenic (C18:3 $\Delta 6.9 .12)$ & $27.4 \pm 0.10 b$ & $0.4 \pm 0.04 \mathrm{e}$ & $0.2 \pm 0.06 \mathrm{~g}$ & $15.8 \pm 1.11 d$ & $1.4 \pm 0.04 \mathrm{~g}$ & $0.7 \pm 0.05 i$ \\
\hline Linolenic (C18:3 $\Delta 9.12 .15)$ & $2.0 \pm 0.13 \mathrm{~g}$ & $29.0 \pm 1.78 a$ & $19.4 \pm 0.25 b$ & $0.9 \pm 0.09 f$ & $30.7 \pm 0.47 a$ & $20.6 \pm 0.37 b$ \\
\hline Steriadonic (C18:4 $\Delta 6.9 .12 .15)$ & $1.1 \pm 0.12 \mathrm{~h}$ & $3.2 \pm 0.08 d$ & $1.7 \pm 0.03 f$ & $0.8 \pm 0.30 f$ & $2.3 \pm 0.22 f$ & $2.0 \pm 0.07 \mathrm{~h}$ \\
\hline & $0.9 \pm 0.04 h$ & $\mathrm{Nd}$ & $0.7 \pm 0.23 g$ & $0.8 \pm 0.05 f$ & $\mathrm{Nd}$ & $\mathrm{Nd}$ \\
\hline Docosanoic (C22:0) & $2.7 \pm 0.10 f$ & $0.04 \pm 0.05 e$ & $0.5 \pm 0.01 \mathrm{~g}$ & $0.4 \pm 0.01 f$ & $\mathrm{Nd}$ & $0.4 \pm 0.05 i$ \\
\hline Docosenoic $(C 22: 1 \Delta 13)$ & $\mathrm{Nd}$ & $2.4 \pm 0.08 d$ & $2.5 \pm 0.01 \mathrm{f}$ & $3.5 \pm 0.03 e$ & $3.0 \pm 0.07 f$ & $4.4 \pm 0.03 f$ \\
\hline
\end{tabular}

${ }^{a} \mathrm{P} 20, \mathrm{~S} 20$ and M20 correspond to P. boryanum, S. obliquus and mixed culture at $20^{\circ} \mathrm{C} ; \mathrm{P} 30, \mathrm{~S} 30$ and M30 correspond to $P$. boryanum, $S$. obliquus and mixed culture at $30^{\circ} \mathrm{C}$. Averages followed by different letters differ statistically from each other $(\mathrm{p}<0.01)$. Lowercase letters compare the levels of different fatty acids in the total composition of FAME in the same treatment. Mean $\pm S D$ ( $\mathrm{n}=3$ cultivations). FAME = fatty acid methyl esters; $\mathrm{Nd}=$ not detected. 
as a proportion of the total FAMEs (Table 6). The most representative fatty acids in all treatments were oleic $(8.2-35 \%)$, linolenic $(0.9-30.7 \%)$, linoleic (8.5-22\%), palmitic (12.2-22.6\%) and gamma-linolenic $(0.2-27.4 \%)$ acids. Other fatty acids were recorded in concentrations considered moderate to low, for example, docosenoic acid (2.4-4.4\%) and stearic acid (1.2-4.1\%).

Oleic fatty acid was predominant in treatments P30 (22.7\%), P20 (30.3\%) and M20 (35.95), which also presented high levels of palmitic (20.9\%), gamma-linolenic acid (27.4\%) and linolenic acids (19.4\%). In S30 (30.7\%) and S20 (29\%), linolenic was the predominant fatty acid, followed by linolenic $(22 \%)$ and oleic $(21.8 \%)$. The M30 treatment was comprised mostly of palmitic $(22.6 \%)$ and linolenic $(20.65 \%)$ fatty acids.

\section{Discussion}

\subsection{Growth}

Although the treatments with the highest $K$ and the shortest $G$ were P30 and P20, the $Y_{\text {max }}$ values for both were statistically lower than those of S30, S20, M30 and M20. When compared to monocultures, mixed cultures showed no increase in biomass and the increase in cell density was only higher relative to the monoculture of $P$. boryanum. Additionally, there was no notable influence of temperature on the calculated parameters. These results differ from those of Phatarpekar et al. (2000), Arkronrat et al. (2016) and Arkronrat \& Oniam (2014) but are similar to the results observed in one treatment in the study by Huang et al. (2011); although all of these studies have worked with mixed cultures, the species and cultivation conditions applied were different from those used in the present study.

The P30 and P20 cultures were the only ones to present a two-day growth induction phase; the stationary growth phase commenced on days 5 and 9 in P30 and P20, respectively. Cultures S20 and M20 did not present an adaptation phase and remained in the exponential phase of growth until the last day of cultivation. The S30 and M30 cultures also did not present an adaptation phase, yet on day showed signs of entry into the steady-state growth phase on day 19 (Table 1).

Although the species in this study are considered cosmopolitan and adaptable to different environmental conditions, there was a dominance relationship in mixed cultures where $S$. obliquus exhibited much higher growth than $P$. boryanum and corresponded to about $80 \%$ of the total culture density. Characteristics such as the size and complexity of the reproductive forms affect the growth rate; when competing for resources, smaller species grow faster. This faster growth rate is because these species have an advantageous surface: volume ratio that facilitates the assimilation of nutrients and available carbon into the culture medium (Phatarpekar et al., 2000; Arkronrat et al., 2016).

\subsection{Total carbohydrates, water-soluble proteins and total lipids}

Past studies indicate an increase of total protein and lipid concentrations as a function of increasing temperature (Juneja et al., 2013; Sayegh \& Montagnes, 2011). However, this trend was not observed in S. obliquus and P. boryanum cultures, likely due to their specific growth conditions.

Koru \& Cirik (2003) cultivated the Cyanophyceae Spirulina platensis (Gomont) Geitler microalgae, commonly used as a food supplement, and noticed a protein content of $58.3 \% \mathrm{DW}$ in cultures performed at $30{ }^{\circ} \mathrm{C}$, which decreased to $45.7 \%$ at $43{ }^{\circ} \mathrm{C}$. Similarly, Rhee \& Gotham (1981) working with Scenedesmus sp., reported this same trend in decreased protein concentration with increasing temperature. In the present study, the protein concentrations increased significantly, from 466.6 to $672.6 \mathrm{mg} \cdot \mathrm{g}^{-1} \mathrm{DW}$ at 30 and $20^{\circ} \mathrm{C}$, respectively, only in the monoculture of $P$. boryanum.

The biomass produced in the mono and mixed cultures of $S$. obliquus and P. boryanum presented protein values considered suitable for application in aquaculture and animal feeding (Tibbetts et al., 2015a). Cultures of Scenedesmus sp., with protein content similar to this study (32-44\% DW), presented six of the ten essential amino acids in higher concentrations than those found in plants, such as soybean and corn (Tibbetts et al., 2015a).

The protein contents found in the cultivation in this research are similar or superior to those described in the literature for plants, such as soybean (40.4\% DW in grain) and bran $(46.7 \%$ DW) (Silva et al., 2006) with variations from 36.82 to $39.85 \%$ DW, depending on the region of the plant in which the grain was harvested (Sales et al., 2016). The values found in the present study are higher than those found in quinoa (14.1\% DW), maize (9.4\% DW) and rice (6.8\% DW) (Nowak et al., 2016).

Contrary to proteins and lipids, there is no effect of temperature on carbohydrate concentrations (Piorreck et al., 1984; Sayegh \& Montagnes, 2011). Fast-growing cells typically have a high protein content and low carbohydrate content. 
The opposite effect is expected with slow growth, when more carbon is directed towards the synthesis of carbohydrates and lipids than proteins (Henderson \& Sargent, 1989; Piorreck et al., 1984; Zhu et al., 1997).

In this study, total carbohydrate levels were below average when compared to other studies on microalgae and vegetables. For instance, 10 $17 \%$ carbohydrate (DW basis) was recovered from S. obliquus (Um \& Kim, 2009), and S. platensis, grown at $30{ }^{\circ} \mathrm{C}$, presented $29.7 \%$ DW basis that significantly increased to $37.6 \%$ when the temperature was raised to $43{ }^{\circ} \mathrm{C}$ (Koru \& Cirik, 2003). Even greater values (581.4 mg.g-1 DW) were observed in Scenedesmus sp., AMDD, grown in wastewater at $20^{\circ} \mathrm{C}$ (Dickinson et al., 2015).

For many species, the total lipid content varies according to growth stage. Values close to the present study were recorded for Selenastrum bibraianum Reinsch (4.7-7.73\% DW), Scenedesmus quadricauda Chodat (6.9-10.6\% DM), Scenedesmus falcatus Chodat (6.4-9.6\% DW), Fragilaria sp. (8.4-9.9\% DW), Chlorococcum sp. (8.7-10.4\% DW) and Chlorella sp. (9.8\% DW) (Abdelkhalek et al., 2016). Total lipid contents higher than those noted for the monoculture of S. obliquus $\left(8.3 \% \mathrm{DW}\right.$ at $\left.30{ }^{\circ} \mathrm{C}\right)$, were previously reported, indicating a production of up to $27 \% \mathrm{DW}$ (Mata et al., 2013).

According to the results presented in this study, there is potential use of this biomass as an alternative supplement for human and animal food. The microalgae of the genus Chlorella, Haematococcus, Dunaliella, Spirulina, Nannochloropsis, Scenedesmus and Schizochytrium are already globally commercialized for this purpose and represent more than $95 \%$ of the current market (Matos et al., 2016; Souza et al., 2018).

The lack of change of carbohydrate and protein concentrations in mixed cultures with the change in temperature suggests that these mixed cultivations are more stable than the monocultures. They are also better suited to withstand great thermal variations, which can vary up to $20^{\circ} \mathrm{C}$ in a single day. This stability ensures uniformity in the biochemical composition of the biomass generated and a constant productivity of the cultivations grown outdoors (Alabi et al., 2009; Coplin, 2012; Smith et al., 2010).

The present study showed an increase in the concentration of total lipids at $20{ }^{\circ} \mathrm{C}$, implying that when targeting the production of these compounds, lower temperatures are recommended when cultivating $P$. boryanum and $S$. obliquus in pre-established nutrient and light conditions.

\subsection{Chlorophyll ' $a$ ' and total carotenoids}

Cultivation time had a marked impact on the production of photosynthetic pigments in all treatments except for P20 and S20, which did not show a significant increase in chlorophyll ' $a$ ' content at the end of the experiment. Similar results were recorded in mixed cultures of Chlorella vulgaris Beyerinck [Beijerinck] and Hyaloraphidium contortum Pascher \& Korshikov. In that instance, the chlorophyll ' $a$ ' concentration increased from $0.41-0.98$ to $0.66-3.17 \mu \mathrm{g} \cdot \mathrm{mL}^{-1}$ and total carotenoids from $0.19-0.39$ to $0.38-1.11 \mu \mathrm{g} \cdot \mathrm{mL}^{-1}$ from the 6th to the 24th day, respectively, in each culture (Brito et al., 2013).

In this study, the values for total carotenoids were well below those found in microorganisms currently used for this purpose in the market. The microalgae Dunaliella salina (Dunal) Teodoresco produces up to $14 \% \mathrm{DW}$ of $\beta$-carotene, with an estimated yield of $102.5 \mathrm{mg} \cdot \mathrm{m}^{-2} \cdot \mathrm{d}^{-1}$ of total carotenoids and $13.5 \mathrm{mg} \cdot \mathrm{L}^{-1} \cdot \mathrm{d}^{-1} \beta$-carotene under ideal conditions (Guedes et al., 2011).

\subsection{Profile of Fatty Acid Methyl Esters (FAMEs)}

MUFAs are an easily digestible energy source. Moreover, in contrast to SFAs, which are non-essential nutrients that increase low-density lipoprotein cholesterol in the blood, MUFAs and polyunsaturated fatty acids (PUFAs) both reduce it, with PUFAs being more potent than MUFAs. Additionally, PUFAs are important in the prevention of immunological, inflammatory and cardiovascular diseases (Huang et al., 2016; Tibbetts et al., 2015a). The high levels of MUFAs and PUFAs, low content of SFAs in the final lipid fraction of the treatments (notably those cultivations at $20^{\circ} \mathrm{C}$ ) and an increase in the total FAMEs, imply that the biomass of $S$. obliquus and P. boryanum is a promising nutrient source.

The mixed cultures (M20 and M30), as well as monocultures of S. obliquus (S20 and S30), possessed high levels of the essential fatty acid alpha-linolenic acid, a natural precursor of the $\omega-3$ fatty acid eicosapentaenoic (EPA). These results are explained by the density dominance of $S$. obliquus over $P$. boryanum at the end of the experiment. The alpha-linolenic acid values were also close to or superior to those found in other studies of microalgae, marketed as Chlorella sp. 
(17.1\%) (Kent et al., 2015) and S. platensis (1.7\%) (Matos et al., 2016). The M20, S20, M30 and S30 cultures also presented lower concentrations of linoleic fatty acid as compared to Chlorella sp. (30.4\%) and higher values than in S. platensis $(2 \%)$.

The $\omega-3 / \omega-6$ ratios recorded in treatments S20 and M20 are optimal. Relatively lower values (2.45:1) were measured in the cultivation of Scenedesmus sp. and cultures of $C$. vulgaris (0.31:1), Micractinium reisseri R.Hoshina, M.Iwataki \& N.Imamura (0.2:1), Nannochloris bacillaris Naumann (0.65:1) and Tetracystis sp. (0.67:1) (Tibbetts et al., 2015b). The $\omega-3 / \omega-6$ ratios established in this study are lower than those verified for fish oils (3-24:1 $\omega-3 / \omega-6)$, which are the most common dietary source of this fatty acid (Tibbetts et al., 2015b). Nonetheless, the ratios were higher than those found in oils produced from commonly consumed oleaginous plants, such as canola $(0.46: 1)$, corn $(0.02: 1)$, olive $(0.08: 1)$ and soybean (0.13:1) oils (Martin et al., 2006). In this context, the biomass from the algae studied here can be used as a dietary supplement in $\omega$-3-deficient diets.

Although animals can convert linoleic $(\omega-6)$ and linolenic $(\omega-3)$ fatty acids into arachidonic acid (AA, C20:4) and EPA (C20:5), respectively, their syntheses are affected by several factors (Martin et al., 2006). Among them, the $\omega-3 / \omega-6$ ratio is fundamental, because $\mathrm{AA}$ and EPA compete for the same lipoxygenase or cyclooxygenase enzymes. Under conditions where there is a low $\omega-3 / \omega-6$ ratio, the synthesis of AA is increased, and that of EPA is reduced, causing immune disorders, cardiovascular and inflammatory diseases (Simopoulos, 2004).

\section{Conclusion}

In this study, the biomass of the analyzed treatments was rich in proteins, essential fatty acids (such as linolenic acid), and had low carbohydrate content, suggesting its potential use as a food supplement. Moreover, the biomass obtained in the $S 20$ treatment presented a high $\omega-3 / \omega-6$ ratio. However, risks should be evaluated and further studies are necessary to assess the approximate chemical composition, evaluation of protein quality and quantity of essential amino acids, fiber content, digestibility, biogenic toxic substances and non-biogenic toxic compounds. Additionally, toxicological and safety evaluations should be considered in order to classify this biomass as a safe functional food.

The results obtained from this research reveal that mixed culture of $P$. boryanum and S. obliquus did not efficiently produce biomass or biochemical compounds when compared to the monocultures. However, algae grown in consortium showed greater stability in their biochemical composition in response to changes in temperatures, an important factor for microalgae cultivation in open ponds and for ensuring the food safety. The interactions between cultivated species, apart from their interactions with external factors, must be considered before the application of mixed cultures in open pond systems. Therefore, more studies should test the interaction between species in mixed cultures, with special focus on the use of species with complementary functional groups to maximize the use of the resources such as light and nutrients.

\section{References}

ABDELKHALEK, E.A.I., MOHAMED, B., MOHAMMED, A.M. and LOTFI, A. Growth performance and biochemical composition of nineteen microalgae collected from different Moroccan reservoirs. Mediterranean Marine Science, 2016, 17(1), 321-330. http://dx.doi.org/10.12681/ mms. 1320 .

ALABI, A.O., TAMPIER, M. and BIBEAU, E. Microalgae technologies \& processes for biofuel/bioenergy production in British Columbia. British Columbia: Seed Science, 2009.

ARKRONRAT, W. and ONIAM, V. Growth performance of mixed culture of microalgae (Chlorella \& Tetraselmis) with monocultures under laboratory conditions. In: Proceedings of 4th International Fisheries Symposium (IFS), Malaysia: ASEAN-FEN, 2014, pp. 30-31.

ARKRONRAT, W., DEEMARK, P. and ONIAM, V. Growth performance and proximate composition of mixed cultures of marine microalgae (Nannochloropsis sp. \& Tetraselmis sp.) with monocultures. Songklanakarin Journal of Science and Technology, 2016, 38(1), 1-5.

BECKER, W. Microalgae for human and animal nutrition. In: A. RICHMOND and Q. HU, eds. Handbook of microalgal culture: applied phycology and biotechnology. 2nd ed. United Kingdom: John Wiley \& Sons, 2013, pp. 461-503. http://dx.doi. org/10.1002/9781118567166.ch25.

BLIGH, E.G. and DYER, W.J. A rapid method of total lipid extraction and purification. Biochem Physiol, 1959, 37(8), 911-917. PMid:13671378.

BRADFORD, M.M. A rapid and sensitive method for the quantitation of microgram quantities of protein utilizing the principle of protein-dye binding. Analytical Biochemistry, 1976, 72(1), 248-254. 
http://dx.doi.org/10.1016/0003-2697(76)90527-3. PMid:942051.

BRITO, D., CASTRO, A., GUEVARA, M., GÓMEZ, E., VILLARROEL, A.R. and ARON, N.M. Biomass and pigments production of the mixed culture of microalgae (Hyaloraphidium contortum and Chlorella vulgaris) by cultivation in media based on commercial fertilizer. AUDJG Food Technology, 2013, 1(1), 5-97.

CHISTI, Y. Biodiesel from microalgae. Biotechnology Advances, 2007, 25(3), 294-306. http:// dx.doi.org/10.1016/j.biotechadv.2007.02.001. PMid:17350212.

CLARENS, A.F., RESURRECCION, E.P., WHITE, M.A. and COLOSI, L.M. Environmental life cycle comparison of algae to other bioenergy feedstocks. Environmental Science \& Technology, 2010, 44(5), 1813-1819. http://dx.doi.org/10.1021/es902838n. PMid:20085253.

COPLIN, L.G. Sustainable development of algal biofuels in the United States. Washington: The National Academies Press, 2012.

CUZZUOL, G.R.F. and CLIPPEL, J.K. Aspectos ecofisiológicos de Sinningia aghensis Chautems em condiçôes de campo. Hoehnea, 2009, 36(1), 73-81. http://dx.doi.org/10.1590/S223689062009000100002 .

DICKINSON, K.E., BJORNSSON, W.J., GARRISON, L.L., WHITNEY, C.G., PARK, K.C., BANSKOTA, A.H. and MCGINN, P.J. Simultaneous remediation of nutrients from liquid anaerobic digestate and municipal wastewater by the microalga Scenedesmus sp. AMDD grown in continuous chemostats. Journal of Applied Microbiology, 2015, 118(1), 75-83. http:// dx.doi.org/10.1111/jam.12681. PMid:25363842.

DISMUKES, G.C., CARRIERI, D., BENNETTE, N., ANANYEV, G.M. and POSEWITZ, M.C. Aquatic phototrophs: efficient alternatives to land-based crops for biofuels. Current Opinion in Biotechnology, 2008, 19(3), 235-240. http://dx.doi.org/10.1016/j. copbio.2008.05.007. PMid:18539450.

DUBOIS, M., GILLES, K.A., HAMILTON, J.K., REBERS, P.A. and SMITH, F. Colorimetric method form determination of sugars and related substaces. Nature, 1956, 28(3), 350-356.

FOGG, G.E. and THAKE, B. Algae cultures and phytoplankton ecology. London: University of Wisconsin Press, 1987.

GORHAM, P.R., MCLACHLAN, R.W. and HAMMER, U.T. Isolation and culture of toxic strains of Anabaena flos-aquae (Lyngb.) de Bréb. Internationale Vereinigung für Theoretische und Angewandte Limnologie: Verhandlungen, 1964, 19(1), 796-804.

GUEDES, A.C., AMARO, H.M. and MALCATA, F.X. Microalgae as sources of carotenoids. Marine Drugs,
2011, 9(4), 625-644. http://dx.doi.org/10.3390/ md9040625. PMid:21731554.

HANNON, M., GIMPEL, J., TRAN, M., RASALA, B. and MAYFIELD, S. Biofuels from algae: challenges and potential. Biofuels, 2010, 1(5), 763-784. http:// dx.doi.org/10.4155/bfs.10.44. PMid:21833344.

HENDERSON, R.J. and SARGENT, J.R. Lipid composition and biosynthesis in ageing cultures of the marine cryptomonad, Chroomonas salina. Phytochemistry, 1989, 28(5), 1355-1361. http:// dx.doi.org/10.1016/S0031-9422(00)97745-8.

HUANG, W., DONG, B., CAI, Z. and DUAN, S. Growth effects on mixed culture of Dunaliella salina and Phaeodactylum tricornutum under different inoculation densities and nitrogen concentrations. African Journal of Biotechnology, 2011, 10(61), 13164-13174.

HUANG, Y., ZHANG, D., XUE, S., WANG, M. and CONG, M. The potential of microalgae lipids for edible oil production. Applied Biochemistry and Biotechnology, 2016, 180(3), 438. http://dx.doi. org/10.1007/s12010-016-2108-6. PMid:27146875.

JUNEJA, A., CEBALLOS, R. and MURTHY, G. Effects of environmental factors and nutrient availability on the biochemical composition of algae for biofuels production: a review. Energies, 2013, 6(9), 46074638. http://dx.doi.org/10.3390/en6094607.

KENT, M., WELLADSEN, H.M., MANGOTT, A. and LI, Y. Nutritional evaluation of australian microalgae as potential human health supplements. PLoS One, 2015, 10(2), e0118985. http://dx.doi.org/10.1371/ journal.pone.0118985. PMid:25723496.

KHAN, S.A., RASHMI., HUSSAIN, M.Z., PRASAD, $S$. and BANERJEE, U.C. Prospects of biodiesel production from microalgae in India. Renewable \& Sustainable Energy Reviews, 2009, 13(9), 2361-2372. http://dx.doi.org/10.1016/j.rser.2009.04.005.

KIRROLIA, A., BISHNOI, N.R. and SINGH, R. Microalgae as a boon for sustainable energy production and its future research and development aspects. Renewable \& Sustainable Energy Reviews, 2013, 20(1), 642-656. http://dx.doi.org/10.1016/j. rser.2012.12.003.

KORU, E. and CIRIK, S. The effects of temperature on growth and some biochemical characteristics of microalgae Spirulina platensis (Cyanophyta). Ege Journal of Fisheries \& Aquatic Sciences, 2003, 20(34), 419-422.

LI, X., HU, H.Y. and ZHANG, Y.P. Growth and lipid accumulation properties of a freshwater microalga Scenedesmus sp. under different cultivation temperature. Bioresource Technology, 2011, 102(3), 3098-3102. http://dx.doi.org/10.1016/j. biortech.2010.10.055. PMid:21055924. 
LORENZEN, C.J. Determination of chlorophyll and phaeophytin: spectrophotometric equations. Limnology and Oceanography, 1967, 12(1), 343-346. http://dx.doi.org/10.4319/lo.1967.12.2.0343.

LOURENÇO, S.O. Cultivo de microalgas marinhas: princípios e aplicaçôes. São Carlos: Rima, 2006.

MARTIN, C.A., ALMEIDA, V.V., RUIZ, M.R., VISENTAINER, J.E.L., MATSHUSHITA, M., SOUZA, N.E. and VISENTAINER, J.V. Omega-3 and omega- 6 polyunsaturated fatty acids: importance and occurrence in foods. Revista de Nutriçāo, 2006, 19(6), 761-770. http://dx.doi.org/10.1590/S141552732006000600011.

MATA, T., MELO, A., MEIRELES, S., MENDES, A., MARTINS, A. and CAETANO, N.S. Potential of microalgae Scenedesmus obliquus grown in brewery wastewater for biodiesel production. Chemical Engineering Transactions, 2013, 32(1), 901-906.

MATOS, Â.P., FELLER, R., MOECKE, E.H.S., OLIVEIRA, J.V., FURIGO JUNIOR, A., DERNER, R.B. and SANT'ANNA, E.S. Chemical characterization of six microalgae with potencial utility for food application. Journal of the American Oil Chemists' Society, 2016, 93(7), 963-972. http:// dx.doi.org/10.1007/s11746-016-2849-y.

MIAO, X., WU, Q. and YANG, C. Fast pyrolysis of microalgae to produce renewable fuels. Journal of Analytical and Applied Pyrolysis, 2004, 71(2), 855863. http://dx.doi.org/10.1016/j.jaap.2003.11.004.

MILLEDGE, J.J. Commercial application of microalgae other than as biofuels: a brief review. Reviews in Environmental Science and Biotechnology, 2011, 10(1), 31-41. http://dx.doi.org/10.1007/s11157010-9214-7.

NOWAK, V., DU, J. and CHARRONDIÈRE, U.R. Assessment of the nutritional composition of quinoa (Chenopodium quinoa Willd.). Food Chemistry, 2016, 193(1), 47-54. http://dx.doi.org/10.1016/j. foodchem.2015.02.111. PMid:26433286.

OHSE, S., DERNER, R.B., OZÓRIO, R.Á., CUNHA, P.C., LAMARCA, C.P., SANTOS, M.E. and MENDES, L.B. Revisão: sequestro de carbono realizado por microalgas e florestas e a capacidade de produção de lipídios pelas microalgas. Insula, 2007, 36(1), 36-39.

PHATARPEKAR, P.V., SREEPADA, R.A., PEDNEKAR, C. and ACHUTHANKUTTY, C.T. A comparative study on growth performance and biochemical composition of mixed culture of Isochrysis galbana and Chaetoceros calcitrans with monocultures. Aquaculture, 2000, 181(1-2), 141-155. http://dx.doi. org/10.1016/S0044-8486(99)00227-6.

PIORRECK, M., BAASCH, K. and POHL, P. Biomass production, total protein, chlorophylls, lipids and fatty acids of freshwater green and blue-green algae under different nitrogen regimes. Phytochemistry, 1984, 23(2), 207-216. http://dx.doi.org/10.1016/ S0031-9422(00)80304-0.

RHEE, G.Y. and GOTHAM, I.J. The effect of environmental factors on phytoplankton growth: Temperature and the interactions of temperature with nutrient limitation. Limnology and Oceanography, 1981, 26(4), 635-648. http://dx.doi.org/10.4319/ lo.1981.26.4.0635.

SALES, V.H.G., PELUZIO, J.M., AFFÉRRI, F.S., OLIVEIRA JUNIOR, W.P. and SALES, P.V.G. Teor de óleo e proteína em grãos de soja em diferentes posiçóes da planta. Agro@mbiente Online, 2016, 10(1), 22-29. http://dx.doi.org/10.18227/19828470ragro.v10i1.2462.

SAYEGH, F.A.Q. and MONTAGNES, D.J.S. Temperature shifts induce intraspecific variation in microalgal production and biochemical composition. Bioresource Technology, 2011, 102(3), 3007-3013. http://dx.doi.org/10.1016/j.biortech.2010.10.011. PMid:20970325.

SILVA, F.A.S. and AZEVEDO, C.A.V. The Assistat Software Version 7.7 and its use in the analysis of experimental data. African Journal of Agricultural Research, 2016, 11(39), 3733-3740. http://dx.doi. org/10.5897/AJAR2016.11522.

SILVA, M.S., NAVES, M.M.V., OLIVEIRA, R.B. and LEITE, O.S.M. Composição química e valor proteico do resíduo de soja em relação ao grão de soja. Food Science and Technology, 2006, 26(3), 571-576. http:// dx.doi.org/10.1590/S0101-20612006000300014.

SIMOPOULOS, A.P. Omega-6/omega-3 essential fatty acid ratio and chronic diseases. Food Reviews International, 2004, 20(1), 77-90. http://dx.doi. org/10.1081/FRI-120028831.

SMITH, V.H., STURM, B.S.M., DENOYELLES, F.J. and BILLINGS, S.A. The ecology of algal biodiesel production. Trends in Ecology \& Evolution, 2010, 25(5), 301-309. http://dx.doi.org/10.1016/j. tree.2009.11.007. PMid:20022660.

SOUZA, M.P., HOELTZ, M., GRESSLER, P.D., BENITEZ, L.B. and SCHNEIDER, R.C.S. Potencial of microalgal bioproducts: general perspectives and main challenges. Waste and Biomass Valorization, 2018, 9(1), 1-18.

SORATANA, K., BARR, W.J. and LANDIS, A.E. Effects of co-products on the life-cycle impacts of microalgal biodiesel. Bioresource Technology, 2014, 159, 157-166. http://dx.doi.org/10.1016/j. biortech.2014.02.070. PMid:24650529.

STRICKLAND, J.D.H. and PARSONS, T.R. A pratical handbook of seawater analysis. Ottawa: Fisheries Research Board of Canada, 1968, 311 p. Bulletin, vol. 167. 
TIBBETTS, S.M., MELANSON, R.J., PARK, K.C., BANSKOTA, A.H., STEFANOVA, R. and MCGINN, P.J. Nutritional evaluation of whole and lipid-extracted biomass of the microalga Scenedesmus sp. AMDD isolated in Saskatchewan, Canada for animal feeds: proximate, amino acid, fatty acid, carotenoid and elemental composition. Current Biotechnology, 2015a, 4(4), 530-546. http://dx.doi. org/10.2174/2211550104666150827201854.

TIBBETTS, S.M., WHITNEY, C.G., MACPHERSON, M.J., BHATTI, S., BANSKOTA, A.H., STEFANOVA, R. and MCGINN, P.J. Biochemical characterization of microalgal biomass from freshwater species isolated in Alberta, Canada for animal feed applications. Algal Research, 2015b, 11(1), 435-447. http://dx.doi.org/10.1016/j.algal.2014.11.011.

UM, B.H. and KIM, Y.S. A chance for Korea to advance algal-biodiesel technology. Journal of Industrial and Engineering Chemistry, 2009, 15(1), 1-7. http:// dx.doi.org/10.1016/j.jiec.2008.08.002.

ZHU, C.J., LEE, Y.K. and CHAO, T.M. Effects of temperature and growth phase on lipid and biochemical composition of Isochrysis galbana TK1. Journal of Applied Phycology, 1997, 9(1), 451-457. http://dx.doi.org/10.1023/A:1007973319348.

Received: 05 October 2018 Accepted: 02 April 2019 